Review began 09/04/2021 Review ended 09/10/2021 Published 09/15/2021

(c) Copyright 2021

Dirim et al. This is an open access article distributed under the terms of the Creative Commons Attribution License CC-BY 4.0., which permits unrestricted use, distribution, and reproduction in any medium, provided the original author and source are credited.

\section{Giant Meckel's Diverticulitis Perforation Due to Necrosis}

\author{
Ahmet Baris Dirim ${ }^{1}$, Sefa Ozyazici ${ }^{1}$ \\ 1. Department of General Surgery, University of Health Sciences, Adana City Training and Research Hospital, Adana, \\ TUR \\ Corresponding author: Ahmet Baris Dirim, drbarisdirim@yahoo.com
}

\begin{abstract}
Although Meckel's diverticulum (MD) is the most common congenital anomaly of the gastrointestinal tract, its prevalence is approximately $2 \%$ in the general population. Most diverticula remain asymptomatic and can be diagnosed with obstruction, perforation, inflammation, and gastrointestinal hemorrhage. The treatment of complicated MD is surgery, but there is no clear treatment recommendation yet for incidentally detected cases. As in the case we present here, the development of perforation due to Giant Meckel's diverticulitis in an adult female patient is a very rare complication of a disease that can be diagnosed very rarely.
\end{abstract}

Categories: General Surgery

Keywords: meckel's diverticulitis, complication, giant, perforation, right-sided abdominal pain

\section{Introduction}

Meckel's diverticulum (MD) is a true intestinal diverticulum caused by incomplete obliteration of the vitelline ducts and located on the antimesenteric margin of the ileum [1]. The prevalence of MD in the general population is $0.3-2.9 \%$ [2]. The majority of the patients remain asymptomatic throughout their lifetime [3]. While the most common complications in pediatric patients are gastrointestinal bleeding and obstruction, complications are secondary to inflammation in adults [4]. Clinical findings vary depending on the complication. Although not specific to MD, the most common symptoms include abdominal pain, vomiting, and fever [5].

As in the case we present here, patients presenting with right lower quadrant abdominal pain are usually operated on with the diagnosis of inflamed or perforated appendicitis in the absence of adequate differential diagnosis [6].

\section{Case Presentation}

A 42-year-old female patient without comorbid diseases was admitted to the emergency department with a two-day history of abdominal pain and nausea associated with an inability to pass gas or stool. Her temperature was $37.5^{\circ} \mathrm{C}$, blood pressure was $100 / 60 \mathrm{~mm} / \mathrm{Hg}$, pulsation was 72 , and respiration rate was 15 breaths per minute. On physical examination, there was right lower quadrant tenderness on palpation. Her digital rectal examination was unremarkable. Normal stomach contents came from the nasogastric tube, and urine output was $30 \mathrm{~mL}$ per hour. Laboratory tests reported high serum levels of C-reactive protein (205 $\mathrm{mg} / \mathrm{L}$ ) and neutrophilic leucocytosis (13,000 white blood cells/ $\mathrm{\mu L})$. On abdominal computed tomography, there was an increase in diffuse wall thickness in the $20 \mathrm{~cm}$ ileal small intestine segment, edema in the mesentery, and air density that could be millimetric extraluminal at this level (Figure 1). 


\section{Cureus}

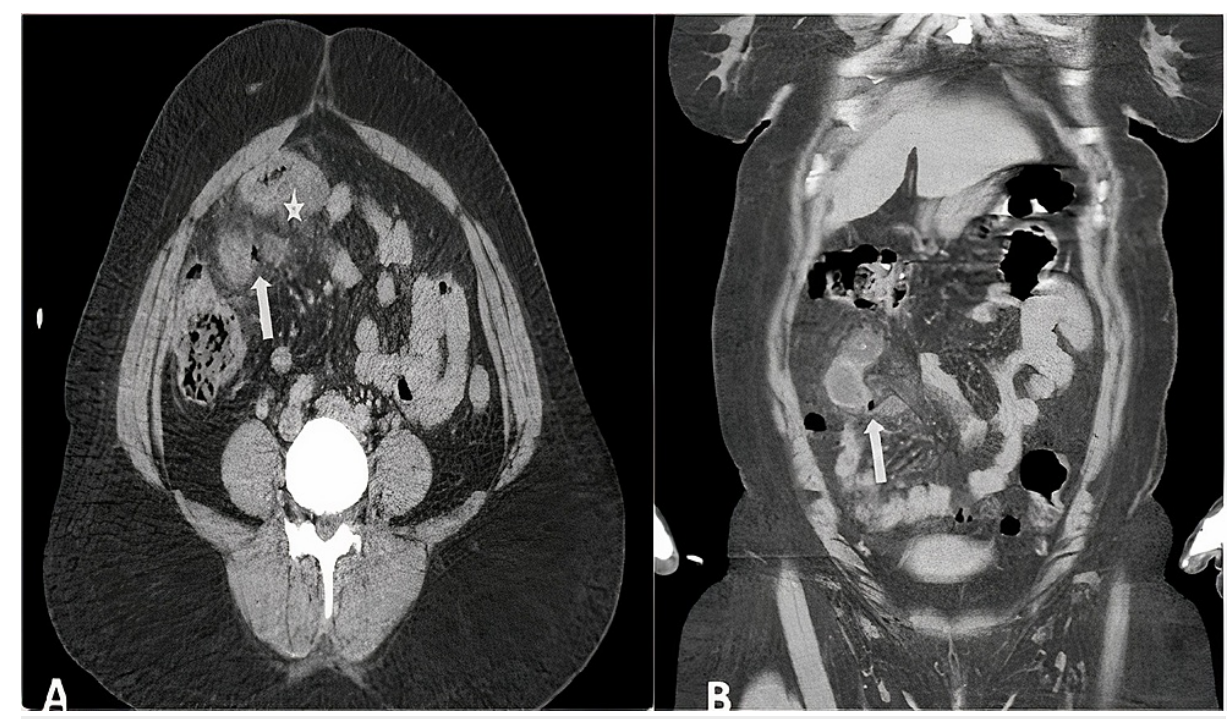

FIGURE 1: Abdominal computed tomography image.

Edema in the small bowel (asterisk) and millimetric air density (arrows).

In view of the clinical and radiological findings, a closed perforation limited to the ileal segment or perforated appendicitis was considered in the differential diagnosis. An exploratory laparotomy was performed which showed that the tip of MD secondary to necrosis was perforated at a distance of $55 \mathrm{~cm}$ from the ileocecal valve with limited abscess (Figure 2).

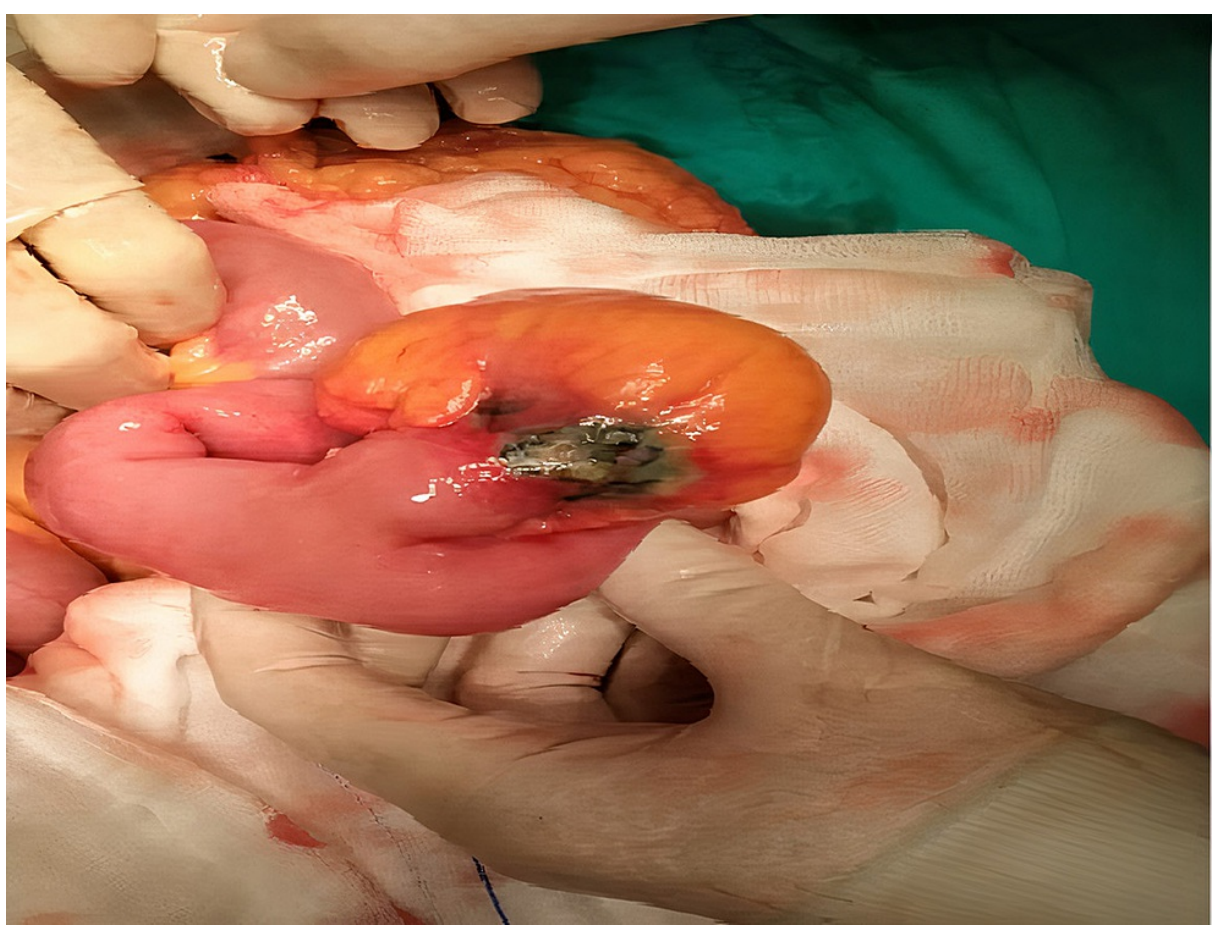

FIGURE 2: Giant Meckel's diverticulitis perforation.

Perforation at the tip due to necrosis with a mushroom appearance.

The ileal segment was resected and an end-to-end enteroenterostomy anastomosis was performed. She was discharged home uneventfully on postoperative day five. Pathological examination of MD revealed

transmural active inflammation without heterotropic tissue measuring $7 \mathrm{~cm}$ in length and $4.5 \mathrm{~cm}$ in width.

\section{Discussion}


Zani et al. [7] reported the lifetime risk of complications due to MD to be $4.2 \%$, while Cullen et al. [8] reported the lifetime risk at $6.4 \%$. In the largest retrospective study, the following four criteria were specified to predict that asymptomatic incidental MD may be complicated: diverticulum longer than $2 \mathrm{~cm}$, male gender, younger than 50 years of age, and presence of ectopic tissue [9]. When one, two, three, or all four criteria were met, the probability of MD to be complicated was reported to be $17 \%, 25 \%, 42 \%$, and $70 \%$, respectively. Our patient met two of the criteria (length and age). The male-to-female gender ratio is 1.5-4:1 in symptomatic patients who have undergone surgery $[10,11]$.

The "rule of $2 \mathrm{~s}$ " summarizes MD: found in $2 \%$ of the population, 2 feet (approximately $61 \mathrm{~cm}$ ) from the ileocecal valve, 2 inches (approximately $5 \mathrm{~cm}$ ) long, may contain two types of ectopic tissue, and most common at two years of age. According to a recent comprehensive systematic review, on average, MD is 3.05 $\mathrm{cm}$ in length, $1.58 \mathrm{~cm}$ in diameter, and $52 \mathrm{~cm}$ from the ileocecal valve [12]. When the diverticula are longer than $5 \mathrm{~cm}$, they are termed giant Meckel's diverticulum, but its prevalence is less than $0.5 \%$ of all MD cases [13].

Whether symptomatic or not, MD is difficult to detect radiologically preoperatively; a $5.7 \%$ rate was reported in a recent review [14]. In another study by Chen et al. [15], 57.5\% of the patients were misdiagnosed and $21.6 \%$ were diagnosed with appendicitis.

MD occurs when a foreign body, such as an enterolith, or tumor occludes the diverticulum lumen, or when the ectopic gastric mucosa secretes acid [16]. In this case, neither obstruction due to foreign body nor ectopic mucosa was noted.

\section{Conclusions}

In the female adult population, symptomatic giant MD is very rare. We believe that it is useful to consider the complications of MD in the differential diagnosis of atypical abdominal pain, where radiological examinations cannot establish a clear diagnosis.

\section{Additional Information \\ Disclosures}

Human subjects: Consent was obtained or waived by all participants in this study. Conflicts of interest: In compliance with the ICMJE uniform disclosure form, all authors declare the following: Payment/services info: All authors have declared that no financial support was received from any organization for the submitted work. Financial relationships: All authors have declared that they have no financial relationships at present or within the previous three years with any organizations that might have an interest in the submitted work. Other relationships: All authors have declared that there are no other relationships or activities that could appear to have influenced the submitted work.

\section{References}

1. Stallion A, Shuck JM: Meckel's diverticulum. Surgical Treatment. Evidence-Based and Problem-Oriented. Holzheimer RG, Mannick JA (ed): Zuckschwerdt, Munich, Germany; 2017.

2. Sancar S, Demirci H, Sayan A, Arıkan A, Candar A: Meckel's diverticulum: ten years' experience. Ulus Cerrahi Derg. 2015, 31:65-7. 10.5152/UCD.2015.2834

3. Lequet J, Menahem B, Alves A, Fohlen A, Mulliri A: Meckel's diverticulum in the adult. J Visc Surg. 2017, 154:253-9. 10.1016/j.jviscsurg.2017.06.006

4. Chen JJ, Lee HC, Yeung CY, Chan WT, Jiang CB, Sheu JC, Wang NL: Meckel's diverticulum: factors associated with clinical manifestations. ISRN Gastroenterol. 2014, 2014:390869. 10.1155/2014/390869

5. Kuru S, Kismet K: Meckel's diverticulum: clinical features, diagnosis and management . Rev Esp Enferm Dig. 2018, 110:726-32. 10.17235/reed.2018.5628/2018

6. Palanivelu C, Rangarajan M, Senthilkumar R, Madankumar MV: Laparoscopic management of symptomatic Meckel's diverticula: a simple tangential stapler excision. JSLS. 2008, 12:66-70.

7. Zani A, Eaton S, Rees CM, Pierro A: Incidentally detected Meckel diverticulum: to resect or not to resect? . Ann Surg. 2008, 247:276-81. 10.1097/SLA.0b013e31815aaaf8

8. Cullen JJ, Kelly KA, Moir CR, Hodge DO, Zinsmeister AR, Melton LJ 3rd: Surgical management of Meckel's diverticulum. An epidemiologic, population-based study. Ann Surg. 1994, 220:564-8; discussion 568-9. 10.1097/00000658-199410000-00014

9. Park JJ, Wolff BG, Tollefson MK, Walsh EE, Larson DR: Meckel diverticulum: the Mayo Clinic experience with 1476 patients (1950-2002). Ann Surg. 2005, 241:529-33. 10.1097/01.sla.0000154270.14308.5f

10. Alemayehu H, Hall M, Desai AA, St Peter SD, Snyder CL: Demographic disparities of children presenting with symptomatic Meckel's diverticulum in children's hospitals. Pediatr Surg Int. 2014, 30:649-53. 10.1007/s00383-014-3513-y

11. Ruscher KA, Fisher JN, Hughes CD, et al.: National trends in the surgical management of Meckel's diverticulum. J Pediatr Surg. 2011, 46:893-6. 10.1016/j.jpedsurg.2011.02.024

12. Hansen CC, Søreide K: Systematic review of epidemiology, presentation, and management of Meckel's diverticulum in the 21st century. Medicine (Baltimore). 2018, 97:e12154. 10.1097/MD.0000000000012154

13. Rana AA, Trochsler M, Kanhere H: Perforated giant Meckel's diverticulum mimicking colonic ischemia . Cureus. 2018, 10:e3753. 10.7759/cureus.3753 


\section{Cureus}

14. Chatterjee A, Harmath C, Vendrami CL, Hammond NA, Mittal P, Salem R, Miller FH: Reminiscing on remnants: imaging of Meckel diverticulum and its complications in adults. AJR Am J Roentgenol. 2017, 209:W287-96. 10.2214/AJR.17.18088

15. Chen Q, Gao Z, Zhang L, et al.: Multifaceted behavior of Meckel's diverticulum in children . J Pediatr Surg. 2018, 53:676-81. 10.1016/j.jpedsurg.2017.11.059

16. Kotha VK, Khandelwal A, Saboo SS, Shanbhogue AK, Virmani V, Marginean EC, Menias CO: Radiologist's perspective for the Meckel's diverticulum and its complications. Br J Radiol. 2014, 87:20130743.

10.1259/bjr.20130743 